\title{
1 GROUPS OF SPECIES RESPONDING TO SOIL AND LIGHT IN THE CERRADO
}

2 Glaucia Soares Tolentino ${ }^{1}$, Cristina Máguas ${ }^{2 *}$, Luiz Fernando Silva Magnago ${ }^{1,3}$, Tillmann Buttschardt ${ }^{4}$,

3 João Augusto Alves Meira-Neto ${ }^{1,2 *}$

$4{ }^{1}$ Laboratory of Ecology and Evolution of Plants - LEEP, Universidade Federal de Viçosa, Campus UFV

5 s/n, Viçosa, State of Minas Gerais, Brazil, 36570-000.

62 Centre for Ecology, Evolution and Environmental Changes - CE3C, Faculdade de Ciências da

7 Universidade de Lisboa, Edifício C2, Lisboa, Portugal, 1749-016.

$8{ }^{3}$ Centro de Formação em Ciências e Tecnologias Agroflorestais, Universidade Federal do Sul da Bahia,

9 Rodovia BR-415, Parque Verde, Itabuna, Bahia State, Brazil, 45604811

$10{ }^{4}$ Institute of Landscape Ecology - ILÖK, University of Münster, D-48149 Münster, Germany.

$11 *$ cmhanson@fc.ul.pt, j.meira@ufv.br

12 JAAMN-ORCID 0000-0001-5953-3942

13 


\section{Abstract}

Woody plants in the Cerrado have been understood to comprise two groups: calcicole species responding to soil $\mathrm{Al}-\mathrm{Ca}$ gradient $(\mathrm{CAL})$ and leguminous species responding to inorganic soil $\mathrm{N}$ gradient (LEG). However, the bulk of Cerrado woody flora was not inside these groups. Our main question was whether CAL and LEG are distinct from each other as well as from the bulk of Cerrado species that occur rather in savannas than in quasi-forests (SAV) while responding only to soil variables and light. We performed the study among five soil categories, and measured canopy openness. We evaluated the functional traits of the 34 most relevant species of the studied Cerrado. We measured specific leaf area, bark thickness, leaf nitrogen, leaf carbon, leaf $\mathrm{C} / \mathrm{N}$, maximum height, maximum, stem elongation, $\delta^{15} \mathrm{~N}$ and $\delta^{13} \mathrm{C}$. We determined wood density by consulting a database. RLQ and Fouth-corner analyses confirmed CAL and LEG as consistent groups as well as found a third group, the SAV. CAL and LEG were found to dominate plots with low canopy openness; only CAL were negatively associated with aluminium saturation; only LEG were negatively associated with $\mathrm{pH}$; only SAV were negatively associated with inorganic nitrogen and CEC. LEG presented the lowest leaf C/N and the highest leaf $\mathrm{N}$ meanwhile SAV presented the highest $\mathrm{C} / \mathrm{N}$, the lowest leaf $\mathrm{N}$ and the lowest stem elongation. Higher values of $\delta^{13} \mathrm{C}$ in leaves suggest higher water use efficiency for CAL and LEG than for SAV.

Keywords: Aluminium, nitrogen, calcicoles, light, $\delta^{13} \mathrm{C}$, water use efficiency. 


\section{Introduction}

A biodiversity hotspot, the Cerrado is one among tropical savannas that occur on acidic soils as some

Australian and African savannas (Materechera et al. 1998; Hutley et al. 2000). In a biodiversity hotspot as the Cerrado, disentangle plant responses to environmental factors is time consuming because the high plant diversity, the soil complexity and a myriad of other environmental variables usually blur the plant-soil patterns and challenge researchers that seek a general interpretation for vegetation responding to soil gradients (de Assis et al. 2011; Neri et al. 2012; Meira-Neto et al. 2017). Grouping species into functional groups with unique ecological attributes (Díaz and Cabido, 2001; Lavorel and Garnier, 2002) frames plant diversity into a few environmentally responsive groups, facilitates the understanding of diverse communities and allows increase complexity step by step. Grouping species of the Cerrado has demanded a long and continuous effort. As far as we know, the first grouping separated the typical woody species that give phytogeographical unity to the Cerrado from species that occur in the Cerrado but occur mainly in other vegetation types, noticeably Atlantic and Amazon forests (Rizzini 1963). Concerning the soil influence on Cerrado plants, plant functional groups have been understood to comprise woody plants responding to the $\mathrm{Al}-\mathrm{Ca}$ gradient (i.e., $\mathrm{pH}$ gradient) and to the inorganic nitrogen gradient (Ratter et al., 1977; Durigan and Ratter, 2006; Meira-Neto et al. 2017). For that, isolating soil from other explanatory environmental variables is important in order to avoid blurring the plant-soil patterns.

Light variation may be included in such studies of tropical savannas as an explanatory variable since it is influenced by soil. Cerrado has high irradiance and typical Cerrado species demand high levels of light (Ribeiro and Walter, 1998). Thus, these species are expected to be displaced in shaded environments by shade-tolerant species (Pinheiro et al., 2016) more adapted to the Cerrado quasi-forests physiognomies (cerradões) with more soil resources. Soil influences Cerrado physiognomies (e.g., (Goodland 1971; Oliveira-Filho and Ratter 2002) and the physiognomic variation promotes a light gradient with species responses (Dalmagro et al. 2014); therefore, canopy cover (i.e., light regime proxy) should be considered as a main ecological factor (Goodland 1971; Goodland and Pollard 1973; Felfili and Fagg 2007; Simon et al. 2009; Dantas et al. 2013) influencing plant growth and soil humidity in Cerrado and in vegetation in general (Valiente-Banuet and Verdú 2007; Meira-Neto et al. 2018). Fire opens Cerrado's physiognomies

60 decreasing coverage of woody species (e.g., (Coutinho 1990; Hoffmann 2002; Simon et al. 2009), 61 influencing light regime. However, in the absence of fire in the Cerrado, soil properties are expected to be 62 the main generators of physiognomic variations as well as the main drivers of light regime. 
The ubiquitous $\mathrm{Al}-\mathrm{Ca}$ gradient is a soil $\mathrm{pH}$ gradient in tropical terrestrial ecosystems that explains much of the physiognomic variation in the Cerrado, from the most oligotrophic and acidic soils (i.e., highest $\mathrm{AL}^{3+}$ content) to the relatively fertile mesotrophic soils (Ratter et al., 1977, 2003). The cation exchange capacity may be taken as a synthesis of soil fertility and is related to Al-Ca gradient is positively related to pH and has been used to explain physiognomic variation (Neri et al., 2013). The levels of exchangeable aluminium are also related to the $\mathrm{Al}-\mathrm{Ca}$ gradient (negatively related to $\mathrm{pH}$ ) and were found as a main source of stress for plants in tropical savannas on acidic soils (Furley and Ratter 1988; Motta et al. 2002; Sugihara et al. 2014). As a result, open physiognomies are associated with dystrophic soils with toxic levels of $\mathrm{Al}^{3+}$ (Goodland and Pollard, 1973; Ruggiero et al., 2002; Neri et al., 2012), thus Al-Ca gradient could determine biomass and abundances in Cerrado (Silva et al., 2013), especially calcicole species. Calcicoles are recognized as functional groups of plants worldwide (Ström 1997; Wohlgemuth and Gigon 2003) and Cerrado is a well-studied tropical savanna concerning calcicoles. The first functional group related to the Cerrado soil was the group of calcicole species (CAL), which respond readily to the Al-Ca gradient (Ratter et al. 1977). These species occur throughout all Cerrado physiognomies, but are dominant in cerradões on mesotrophic soils (mesotrophic cerradões) (Ratter et al. 1977; Durigan and Ratter, 2006) and are commonly found as dominant species in tropical dry forests on limestone hills (Oliveira-Filho et al., 2006; Meira-Neto et al., 2017).

Another functional group, the nitrogen-fixing leguminous trees (LEG) occur throughout Cerrado physiognomies, but dominate the cerradões on acidic dystrophic soils (dystrophic cerradões) (Meira-Neto et al., 2017). Therefore, dystrophic cerradões are quasi-forest physiognomies with high abundance of trees, with much higher biomass than open savannas, also occur on dystrophic and acidic soils with high levels of $\mathrm{Al}^{3+}$ and with high levels of inorganic nitrogen dominated by leguminous nitrogen-fixers (Goodland 1971; Oliveira-Filho and Ratter 2002; Meira-Neto et al. 2017).

These two groups, CAL and LEG, were found to respond in opposite ways to the Al-Ca gradient, with CAL biomass and abundances positively associated with $\mathrm{pH}$ and negatively with inorganic nitrogen at the uppermost soil layers, and LEG biomass and abundances negatively associated with $\mathrm{pH}$ and positively with inorganic nitrogen at the uppermost soil layers (Meira-Neto et al. 2017). However, this CAL-LEG model only considers the gradient between mesotrophic soils with higher $\mathrm{pH}$ and dystrophic soils with 
Climate, altitude, topography, water table and fire are important rulers of the Cerrado functioning and physiognomic variation (Rossatto et al. 2012; Cianciaruso et al. 2012; Dantas et al. 2013; Franco et al. 2014). Without variation of climate, of altitude, of topography, of water table depth and of disturbances (mainly fire), the woody species of Cerrado respond essentially to soil and light. In such a situation, the growth of woody species should respond to light, to soil humidity, to $\mathrm{N}$, to $\mathrm{P}$, to $\mathrm{K}$ and to $\mathrm{Mg}$ soil concentrations as well as to the soil Al-Ca gradient (Goodland and Pollard 1973; de Assis et al. 2011; Neri et al. 2012). The CAL and the LEG are in different situations on the gradient of inorganic soil nitrogen as nitrogen is a key factor for plant growth and development (Sprent 2007, 2009), especially in oligotrophic soils (Bustamante et al. 2004). Therefore, the inorganic soil nitrogen can vary independently from the most of soil nutrients along the Al-Ca gradient. Moreover, the other species that are not CAL or LEG comprise a species-rich set of woody plants in the Cerrado and their responses to environmental factors of the Al-Ca gradient working along with the inorganic-N gradient are still unkonown. This work aims to answer i) whether without influence of other main environmental variables, CAL and LEG are distinct from each other as well as from the set of other species considering their responses to soil factors and to light regime in the analyses. Another question is ii) whether the other Cerrado species that are not CAL and LEG can be encompassed as typical Cerrado savanna-species (SAV) sensu Rizzini (1963). A final question is iii) whether these analyses reveal additional axes that explain the environmental gradient of the Cerrado (and possibly of tropical savanna on acidic soils). In order to test the soil and light effects, avoiding other

111 environmental biases, we sampled a Cerrado with plots in five different soil types with minimum variation in topography, in altitude, within the same climate, within the same fragment (i.e., the same landscape) and without fire disturbance for more than 50 years. For that, we analysed and modelled soil factors and canopy openness for all plots as well as we analysed and modelled leaf contents of nitrogen, of carbon, leaf $\delta 13 \mathrm{C}$, leaf $\delta 15 \mathrm{~N}$, maximum plant height, maximum stem diameter, bark thickness, wood density and specific leaf area for all plots and for all sampled species of woody plants.

\section{Material and methods}

\section{Study area}

The study was carried out in the 200- ha Paraopeba Reserve in the state of Minas Gerais $\left(19^{\circ} 20^{\prime} \mathrm{S}\right.$,

$12144^{\circ} 20^{\prime} \mathrm{W}$ ), Brazil. The climate of the region is classified as Aw (tropical humid) by the Köppen system with 122 a rainy summer from October to April and a dry season from May to September. The mean annual 123 temperature and mean annual rainfall are $20.9^{\circ} \mathrm{C}$ and $1328 \mathrm{~mm}$, respectively. The vegetation of the reserve 
124 is the product of regeneration after clear-cutting in 1952. There are records of fires in 1960 and 1963, since which the area as a whole has been protected from fire (Neri et al. 2012).

We carried out the study on a wide range of soils spread over a short distance, where differences in vegetation are ascribed to soil attributes since variation in climate and topography was negligible (Neri et al. 2012).

The soils are classified as i) dystrophic Haplic Cambisol, ii) Yellow Latosol, iii) Red-Yellow Latosol, iv) dystrophic Red Latosol and v) mesotrophic Red Latosol (EMBRAPA 2006; Neri et al. 2012).

131 Along this gradient the dark-redder the soil the greater the biomass and density of woody plants. Colluvial 132 materials from weathered limestone or in situ alteration of such calcareous rocks influence both eutrophic 133 and dystrophic red soils. On the other hand, Cerrado savannas are related to either shallow or deep yellowish 134 soils (Cambisols/Latosols) developed from slate, a pellitic Al-rich nutrient-poor metamorphic rock. Since 135 there is a wide range of soil characteristics within a small area, this fragment of Cerrado is a suitable system 136 for increasing knowledge regarding plant functional groups with different strategies for resource use and stress tolerance without climatic, topographical and dispersion limitation biases.

\section{Vegetation, soil and light}

The structure of the woody layer was evaluated by equally distributing 24 plots (20-m x 20-m)

140 along the aforementioned soil gradient. We sampled three plots of Inceptisol (Cambisol), three plots of 141 mesotrophic Red Latossol, three plots of dystrophic Red Latossol, six plots of Yellow Latosol and nine 142 plots for Red-Yellow Latossol (Yellow Latosol and Red-Yellow Latosol are intermediary soils with more 143 plots to better represent the intermediate portion of the gradients). All plots were randomly selected inside 144 soil types areas. The soil characterization is in previous publications (Neri et al. 2012, 2013). From July 1452011 to September 2012 we recorded all individual woody plants with stem circumferences equal to or 146 greater than $10 \mathrm{~cm}$ at ground level. The classification of species into families followed APG IV (The 147 Angiosperm Phylogeny Group 2016), with the nomenclature of species and abbreviations being in 148 agreement with Brazilian Flora Checklist (www.floradobrasil.jbr.gov.br). Soil samples were collected from all 20-m x 20-m plots, each one comprising 10 subsamples from 150 a depth of $0-10 \mathrm{~cm}$. Soil samples taken for chemical analysis were air-dried and sieved. Since Cerrado soils 151 generally possess low nutrient status and fertility, which have been shown to influence its vegetation, we 152 used cation exchange capacity (CEC), inorganic $\mathrm{N}$ and $\mathrm{pH}$ as proxies for soil fertility. Furthermore, since 153 aluminium saturation determines the fraction of $\mathrm{Al}^{3+}$ in $\mathrm{CEC}$, it was considered a main soil factor. The $\mathrm{pH}$ 
) and ammonium $\left(\mathrm{NH}_{3}\right)$ content. Colorimetric analyses were used for measuring $\mathrm{NO}^{3-}$ and $\mathrm{NH}_{3}$. All analyses were performed in the Soil Laboratory at the Universidade Federal de Viçosa, following methods for Brazilian tropical soils (EMBRAPA, 1997).

Canopy openness was measured as a proxy for light availability by taking hemispherical photographs (Beaudet and Messier 2002). The photos were taken using a Nikon Coolpix 5700 digital camera, with a Nikon UR-E12 extender and a Nikon FC-E9 fisheye lens, supported at $1.5 \mathrm{~m}$ above the ground by a tripod with the zenith centred and a north orientation. The photos were taken at dusk or during perfectly overcast days (Breshears and Ludwig, 2010) during the middle and the end of the rainy season (February 2012) when the canopy cover was maximum and light could act as a limiting factor for plants. Each plot was divided into four 10-m x 10-m subplots and photos were taken at the center of each sobplot. Photos were analyzed with Gap Light Analyzer (GLA) software (Frazer et al. 1999). Canopy openness values were obtained for each plot by averaging canopy openness of four 10-m x 10-m subplots.

In order to choose the dominant species that totalize $\sim 75 \%$ of abundance, we used data from a previous survey on 3 hectares with 15 plots of 20-m x 20-m on each soil type, 75 plots in total. We found 14,671 individuals of 174 woody species of 51 families in the woody communities of the studied vegetation. Of these, 10,866 individuals belonged to the 34 species that made up $74.06 \%$ of the total abundance of the community. We used the 75 plots only to choose that 34 species with $75 \%$ of abundance. All other analyses used the 24 chosen plots. Thus, those 34 species were sampled and analysed in the 24 chosen plots previously described.

\section{Functional traits}

Despite the high floristic richness of the Cerrado, the abundance of the woody community are usually dominated by a few species. As $75 \%$ of dominance is the lower limit for highest level of dominance for sampling vegetation methods as Braun-Blanquet and Domin-Krajina (Mueller-Dombois and Ellenberg 2003; Maarel 2009), we considered the species that collectively comprise $\sim 75 \%$ of the local abundance as rulers of the Cerrado functioning. Thus, we evaluated functional traits for 34 selected species, which accounted for $74.06 \%$ of the cumulative relative abundance in the Cerrado of Paraopeba Reserve. All individuals of selected species were assessed for measuring traits.

Trait-based analysis requires selection of critical traits to the community processes of interest (Kraft et al. 2007). Six key traits (Table 1) related to competitive ability, resources use and tolerance were used (Cianciaruso et al. 2012; Pérez-Harguindeguy et al. 2013). Wood density was determnined by the 

wood density was obtained from the online database, it had no variability. Other traits were measured by widely accepted methods (Cornelissen et al. 2003; Pérez-Harguindeguy et al. 2013). The sampling was plot-specific, which allowed us to assess environmental factors (Cianciaruso et al. 2009). Thus, we used functional traits measured on individuals of a plot as a proxy of functional traits of that plot.

\section{Carbon, nitrogen and stable isotopes analyses $\left(\delta^{13} \mathrm{C}\right.$ and $\left.\delta^{15} \mathrm{~N}\right)$}

We used stable isotopes analyses in order to understand the conditions of functional groups and set of species in each plot under different soil and light conditions. Three leaves healthy and fully developed from all individuals sampled in each plot were taken during the rainy season (March of 2013). The leaves were sampled at a similar distance from the ground and at the north side of the canopy. The leaves were dried to constant weight $\left(65^{\circ} \mathrm{C}\right)$ without petioles and midribs and ground to a powder using a ball mill (Retsch, Haan, Germany) for measuring carbon, nitrogen, $\delta^{13} \mathrm{C}$ and $\delta^{15} \mathrm{~N}$. Nitrogen and carbon concentration, and $\delta^{13} \mathrm{C}$ and $\delta^{15} \mathrm{~N}$ were analysed using an elemental analyzer (HEKAtech, Weinberg, Germany) with a continuous-flow stable isotope ratio mass spectrometer (ISOPRIME, GV, Manchester, presented in $\delta$ notation: leaves.

where $R_{\text {standard is }}$ the ${ }^{15} \mathrm{~N} /{ }^{14} \mathrm{~N}$ ratio of atmospheric $\mathrm{N}_{2}$ and $R_{\text {sample }}$ is the ${ }^{15} \mathrm{~N} /{ }^{14} \mathrm{~N}$ ratio of the sampled leaves. The repeated measurement precision was $0.2 \%$.

\section{Species groups and data analysis}

Different groups of woody species were considered based on the dispersion of species along the ordination axis of a multidimensional scaling - MDS using two functional traits as variables for species: 
mean leaf $\mathrm{C} / \mathrm{N}$ and mean aluminium saturation. Mean leaf $\mathrm{C} / \mathrm{N}$ was calculated as arithmetic mean of leaf

$\mathrm{C} / \mathrm{N}$ of all individuals of each species. Mean aluminium saturation was calculated giving the aluminium

saturation of soil of each plot to each individual occurring in that plot; then, was calculated the arithmetic mean of aluminium saturation among individuals of each species. The CAL was considered the calcicoles species occurring in the Cerrado with lowest aluminium saturation means. LEG are the leguminous woody species that occur in the Cerrado, most of them belonging to nitrogen-fixing genera (Sprent 2009) as well as other species with the lowest leaf $\mathrm{C} / \mathrm{N}$. SAV were the woody species with the highest leaf $\mathrm{C} / \mathrm{N}$. and are not nitrogen-fixing.

In order to investigate relationships between soil and light effects and abundance of the found species groups, we created generalized linear models (GLMs) applying abundance as a response variable of soil cation exchange capacity (CEC), of soil $\mathrm{pH}$, of soil inorganic $\mathrm{N}$, of soil aluminium saturation and of canopy openness.

We constructed a numerical matrix, with averaged values of SLA, ratio of maximum height to maximum diameter (Hmax/Dmax) as stem elongation, leaf $\mathrm{C} / \mathrm{N}$, bark thickness and woody density for the 34 species and species-weighted averaged values for CAL, LEG and SAV in plots.

\section{Statistical analysis}

RLQ analysis was carried out using the functions 'dudi.coa', 'dudi.hillsmith', 'dudi.pca' and 'rlq' of the ade4 package (Dray et al. 2018) for canonical ordination of species abundances, functional traits (SLA, Hmax/Dmax, $\% \mathrm{C}$ and $\% \mathrm{~N}$ ), plots and three soil variables (CEC, aluminium saturation and inorganic nitrogen, all square-rooted transformed). The Fourth-corner analysis was carried out using the 'fourthcorner' function of the Ade4 package performing 50000 permutations with FDR adjustment of $\mathrm{P}$ values for multiple comparisons between the soil variables and the functional traits of the RLQ analysis (Peres-Neto et al. 2017; Braak et al. 2018). All analyses were performed within the R statistical environment

(R Development Core Team, 2015). The canonical ordination was the basis on which the groups CAL,

LEG and SAV were proposed.

ANOSIM test was performed for testing the 34 species divided into the three groups by means of the SLA, Hmax/Dmax, $\% \mathrm{C}$ and $\% \mathrm{~N}$ for calculation of Euclidean Distance dissimilarity using the functions 'dist'and 'anosim' from the 'Vegan' package in R statistical environment (R Development Core Team 2015).

GLMs were carried out using the 'glm' function of the MASS package with Poisson error distribution for count data (i.e., abundance) to test the response of CAL, LEG and SAV abundances to soil $\mathrm{pH}$, to soil 
248 inorganic $\mathrm{N}$, to soil aluminium saturation and to canopy openness. All explaining variables were scaled.

249 We used the dredge function of the MuMIn package (Bartón 2018) to select the models that explain our 250 data among all possible combinations of two predictive variables that are not correlated $(\mathrm{r}<0.6$, 251 https://github.com/rojaff/dredge mc) or one predictive variable (i.e., overfitting avoidance). The Akaike 252 Information Criterion (AIC) was used to select the best models (Symonds and Moussalli 2011), and all 253 models with $\triangle$ AIC less than 2 was considered equally parsimonious. From all selected models, we 254 calculated average parameters and unconditioned standard errors weighted by the likelihood ratio using the 255 'model.avg' function of the MuMIn package. The function performs significance tests for each predictor 256 estimated in this average model. The final model will be validated by plotting residual $\mathrm{x}$ adjusted values, 257 residual versus predictors and observing the distribution of residues. All analyses were performed within 258 the R statistical environment (R Development Core Team 2015).

For each one of the 34 species was calculated a mean value for each functional trait. Then were 260 calculated mean values for each functional group based on the values of each species. GLMs with gaussian 261 error distribution were preformed using the glm function of the MASS package to test differences between 262 means of groups for leaf $\mathrm{C} / \mathrm{N}$, leaf nitrogen content, specific leaf area, woody density, bark thickness and 263 Hmax/Dmax (stem elongation). The difference between groups for each functional trait was additional 264 tested using dunnTest function of the dunn.test package in cases that the differences between groups were 265 dubious by GLMs. All analyses were performed within the R statistical environment (R Development Core 266 Team 2015).

\section{Results}

The RLQ analysis showed that three groups of species were related manly to stem elongation $(\mathrm{H} / \mathrm{DSH})$, specific leaf area (SLA), leaf nitrogen contents $(\% \mathrm{~N})$ and leaf carbon contents $(\% \mathrm{C})$. The 34 271 woody species were grouped into three groups proposed based on the canonical ordination of RLQ: 272 Calcicole species (CAL) mainly associated to high H/DSH and high SLA, leguminous species (LEG) 273 mainly associated to high \%N and high \%C, and savanna species (SAV) mainly associated to low H/DSH, 274 low SLA, low \%N and low \%C (Figure 1, Appendix S1). The ANOSIM analysis testing the consistency of 275 the three proposed groups with 34 species responding to SLA, Hmax/Dmax, $\% \mathrm{C}$ and $\% \mathrm{~N}$ was significant $(\mathrm{p}=0.01796)$. 
The fourth-corner analysis showed that the H/DSH and SLA are positively related to soil CEC and negatively related to soil aluminium saturation $(\mathrm{m})$. Leaf nitrogen contents $(\% \mathrm{~N})$ and leaf carbon contents $(\% \mathrm{C})$ are positively related to soil inorganic nitrogen (Figure 2).

The best GLM full models (i.e., two uncorrelated variables for each species group $[\mathrm{r}<0.6]$, delta $\mathrm{AIC} \leq 2$, Appendix S2) for CAL species showed aluminium saturation, and canopy openness as explanatory variables of abundance (Figure 3). LEG species, the best full models (i.e. two uncorrelated variables $[r<0.6]$, delta $\mathrm{AIC} \leq 2$, Appendix S2) showed $\mathrm{pH}$, and canopy openness as explanatory variables negatively associated with abundance (Figure 4). The best full models for SAV species (i.e. two uncorrelated variables $[\mathrm{r}<0.6]$, delta $\mathrm{AIC} \leq 2$, Appendix S2) showed inorganic nitrogen, and CEC as explanatory variables of abundance (Figure 5, Table 1). All selected models were negative relations between abundance of species groups and environmental variables. CAL were severely limited by aluminium toxicity and excessive light indicating that excessive light and high aluminium are a damaging combination. The CAL limitation by aluminium saturation is clearly a stress limitation since aluminium is a known and ubiquitous stress in plants (Kochian 1995; Jansen et al. 2002). The CAL limitation by canopy openness is likely light stress caused by photon flux density higher that used by photosynthesis. This light stress would be caused by excessive light or by photosynthesis limitation because of indirect stressors as aluminium (i.e., the other variable of the global model) that limit root growth and nutrient uptake (Demmig-Adams and Adams 1992; Akaya and Takenaka 2001). LEG were strongly limited by increasing $\mathrm{pH}$ and to increasing light, in a deleterious combination of high $\mathrm{pH}$ and excessive light stresses. Possibly in the LEG case, interconnected stresses are acting since the light stress is caused combined with $\mathrm{pH}$ increasing, which is possibly an effect of photosynthesis limitation caused by a low phosphorus uptake in soils with higher pH (Riley and Barber 1971; Hocking 2001; Thomas et al. 2006). SAV species are not benefitted from the increasing resources of soil inorganic nitrogen and soil CEC. Thus, the SAV limitation not caused by stresses, but the lack of ability to use efficiently soil resources (i.e., inorganic nitrogen and CEC) to grow.

Among the 34 species (fourteen CAL, six LEG, fourteen SAV) CAL presented greater specific leaf area (SLA) than SAV, LEG presented the highest leaf nitrogen content and SAV the lowest, SAV 304 SAV and CAL and LEG presented higher stem elongation (Hmax/Dmax) than SAV. Bark thickness was not different between groups, but CAL presented low variance and SAV presented high variance (Figure 7). 
bioRxiv preprint doi: https://doi.org/10.1101/2020.02.20.955955; this version posted February 20,2020 . The copyright holder for this preprint (which was not certified by peer review) is the author/funder, who has granted bioRxiv a license to display the preprint in perpetuity. It is made available under aCC-BY-ND 4.0 International license.

neither differed significantly nor was related to any other functional trait (data and results not shown).

\section{Discussion}

CAL, LEG and SAV species can be used as different groups of species responding to environmental variables and with different functional profiles. CAL, LEG and SAV abundances responded differently to the explanatory variables of soil and to canopy openness of (i.e., light). CAL, LEG and SAV differed from each other in leaf traits (i.e., nitrogen content, $\mathrm{C} / \mathrm{N}$ and SLA) and in stem traits (wood density and Hmax/Dmax) indicating distinctive functioning. Therefore, the CAL, LEG and SAV presented distinctive abundance responses to soil/light variables as well as distinctive set of functional traits. The proposed species grouping was significantly consistent with the traits SLA, Hmax/Dmax, $\% \mathrm{C}$ and $\% \mathrm{~N}$ as well as the soil variables.

CAL abundance was the only group negatively related to aluminium saturation. CAL was negatively related to canopy openness as well. CAL presented greater stem elongation and greater SLA compared to SAV, indicating that CAL species are associated with more fertile soils of higher productivity than SAV, congruently to their high SLA (Reich et al. 1997; Westoby 1998). The deciduousness (i.e., short leaf lifespan) of the most of CAL species (Oliveira-Filho et al. 2006) suggests also high productivity (Reich et al., 1997) in plots dominated by CAL species. Therefore, functional traits and responses to environmental variables that distinguish CAL species are related to competition ability for light, to long lifespan (i.e., high Hmax/Dmax, low canopy openness and high wood density), to habitats with high productivity (i.e., high SLA) (Westoby 1998; Moles et al. 2009; Pérez-Harguindeguy et al. 2013; Kunstler et al. 2016) as well as to intolerance to soil stress.

The abundance of LEG was negatively related to $\mathrm{pH}$, and to canopy openness. Their low leaf $\mathrm{C} / \mathrm{N}$ and highest leaf nitrogen content are congruent with the nitrogen-fixing function and with low canopy openness (Bustamante et al. 2004, 2006). Functional traits and environmental variables that distinguish LEG species are related to competition for light, to long lifespan (i.e., medium to high wood density and low canopy openness), to high nitrogen status (i.e., low $\mathrm{C} / \mathrm{N}$ and high leaf nitrogen), to soil nutritional stress-tolerance (i.e., low pH).

The SAV abundance is negatively related with soil inorganic nitrogen and with CEC. The negative relation of SAV abundance with soil resources are congruent with their low SLA, suggesting suitability to habitats with low productivity (Dantas et al. 2013; Pérez-Harguindeguy et al. 2013). Functional traits 
suggest SAV species as bad competitors for light with short lifespan (i.e., low stem elongation and low wood density), tolerant to soil-nutritional stress of habitats with low productivity (i.e., high $\mathrm{C} / \mathrm{N}$, low leaf nitrogen content, low SLA, low soil CEC and low inorganic soil N).

Within CAL species, there are six species that would be grouped separately forming another intermediate group or even be placed into another group. However, as the objective of the grouping is to decrease diversity in order to find the main soil and light influences in the Cerrado, we chose to use three groups. Therefore, our choice was to include Alibertia edulis, Erythroxylum daphnitis, Lithraea molleoides, Myrsine umbellata, Pera glabrata and Terminalia argentea inside CAL group.

From that first grouping effort that listed 'Cerrado typical species' and separated them from species that 'mainly occur in other vegetation types' (Rizzini 1963), the CAL (calcicoles) were in the species list that mainly occur in other vegetation types (Ratter et al. 1977; Oliveira-Filho et al. 2006; Durigan and Ratter 2006) and the LEG had species in both lists (Meira-Neto et al. 2017). The Cerrado typical species sensu Rizzini (1963) are the bulk of SAV, but some SAV were listed as species that 'mainly occur in other vegetation types' by the author. It is the case of Callistene major, Curatella americana, Miconia albicans, Styrax camporum, Tapirira guianensis and Vochysia tucanorum. Therefore, the Rizzini's groups may be a good hint, but they are not consistent functionally.

The negative relation between $\mathrm{C} / \mathrm{N}$ and $\delta^{13} \mathrm{C}$ among all groups show that the higher the $\mathrm{N}$ nutritional status, the more the ${ }^{13} \mathrm{C}$ proportion in leaves. A possible explanation of low $\delta^{13} \mathrm{C}$ in some of these species may be that deep roots can access water during the dry season on deep soils in Cerrado (Rawitscher et al. 1943; Ferri 1944; Rachid 1947; Rossatto et al. 2012). Therefore, low ${ }^{13} \mathrm{C}$ proportion might be because the higher stomatal conductance and high $\mathrm{CO}_{2}$ assimilation rates lower the $\delta^{13} \mathrm{C}$ as Rubisco freely discriminates and prefers ${ }^{12} \mathrm{C}$ to ${ }^{13} \mathrm{C}(\mathrm{Kohn}, 2010)$. Thus, the high nitrogen status associated with high $\delta^{13} \mathrm{C}$ may enhance drought tolerance (Wright et al. 2001, 2003) and should be further investigated in LEG and CAL that presented lower $\mathrm{C} / \mathrm{N}$ than SAV. The high $\delta 13 \mathrm{C}$ in leaves suggest stomatal closure as well as higher water use efficiency (Goldstein et al. 1989; Scartazza et al. 1998). The $\delta^{13} \mathrm{C}$ of the cerradões dominating groups $(\mathrm{CAL}+\mathrm{LEG})$ is higher than the $\delta^{13} \mathrm{C}$ of $\mathrm{SAV}(\mathrm{p}=0.0317$, GLM, gaussian distribution, results not shown). Therefore, our results suggest that ecosystems dominated by CAL and LEG (cerradões) are on soils with higher nutritional status, with less canopy openness and rather tolerate drought stress more than open Cerrado plots dominated by SAV. Considering that $\delta^{13} \mathrm{C}$ enrichment is associated to stomatal closure as a response to drought stress, ${ }^{13} \mathrm{C}$ enriched functional groups can tolerate longer periods of water 
stress (Werner and Máguas 2010; Máguas et al. 2011) than SAV (i.e., ${ }^{13} \mathrm{C}$ depleted functional group).

Moreover, decreased leaf C/N of LEG and CAL may to improve plant growth and canopy coverage. Thus,

higher $\delta^{13} \mathrm{C}$ values suggest longer periods of biomass incorporation during droughts and different phenological developments (Werner and Máguas 2010). Therefore, the results show that as leaf $\mathrm{C} / \mathrm{N}$ decreases, leaf $\delta^{13} \mathrm{C}$ increases, drought tolerance increases and water use efficiency increases, similarly to found results of other studies (Goldstein et al. 1989; Scartazza et al. 1998; Coletta et al. 2009). As CAL and LEG are ${ }^{13} \mathrm{C}$ enriched and dominate cerradões, the relation between high nitrogen status and high water use efficiency must be further assessed in CAL and LEG.

Despite the reported evidence of nitrogen fixation by nodulated genera in the Cerrado (Sprent $e t$ al. 1996), our results of leaf $\delta^{15} \mathrm{~N}$ were not significant. However, the proportion of this stable isotope should be further studied in both soil and plants to determine whether the sources of $\mathrm{N}$ for the different functional groups are the same (Marshall et al. 2007; Craine et al. 2015), and whether there are ecological processes involved in nitrogen uptake by plants (e.g., mycorrhizal and nitrogen-fixing bacteria associations). In addition to $\delta^{15} \mathrm{~N}$, the existence of variation in leaf $\mathrm{N} / \mathrm{P}$ among groups of species should be determined (Bustamante et al., 2004, 2006; Townsend et al., 2007). Copaifera was the only leguminous genera that is not considered nitrogen fixing among LEG (Sprent 2009) and deserves attention in future studies concerning nitrogen fixing species.

Based on the GLMs results and fourth-corner analysis, we propose a model with three main gradients and two functional traits to explain the responses of CAL, LEG and SAV: canopy openness, soil aluminium saturation, $\mathrm{pH}, \mathrm{CEC}$, and soil inorganic nitrogen. The model presented in Figure 9 shows the main gradient for each functional group. CAL, associated with high SLA, dominate soils/plots with low aluminium saturation, and low canopy openness. LEG, associated to low $\mathrm{C} / \mathrm{N}$, dominate soils/plots with high $\mathrm{pH}$ and with low canopy openness. The SAV, associated to low stem elongation, dominate soils/plots with low inorganic nitrogen low CEC and with low inorganic nitrogen. That model was proposed based on the figures 1 to 8 and respective statistical tests. The model is hypothetical and should be tested in any tropical savannas on acidic soils.

The proposed model may generate hypotheses and questions for different situations throughout the Cerrado and other tropical savannas. The first question maight be how general is the model. The hypotheses derived from each side of the triangle would deepen the understanding of particular situations in the Cerrado, as demonstrated by the side represented between the mesotrophic and dystrophic cerradões gradient (CAL-LEG) (Meira-Neto et al. 2017) which would be interpreted as the merged red and green 
398 gradients of the model. Thus, are the mesotrophic cerradões-savanna gradient (CAL-SAV) as well as

399 dystrophyc cerradões-savanna gradient (LEG-SAV) the resulting merged gradients of the other triangle

400 sides? What would be the responses of the groups where one of them is underrepresented or even missing? 401

\section{Acknowledgements}

403 The authors thank CNPq (proc. 446698/2014-8), FAPEMIG (PPM 0584-16), PIRSES (GA-2010-269206),

404 CAPES and PPGBot/UFV for scholarships, grants and financial support. The authors also thank the 405 Paraopeba Reserve staff for providing help and facilities. JAAMN has a productivity fellowship from CNPq 406 (307591/2016-6). The research complies with the current Brazilian law. 
bioRxiv preprint doi: https://doi.org/10.1101/2020.02.20.955955; this version posted February 20, 2020. The copyright holder for this preprint (which was not certified by peer review) is the author/funder, who has granted bioRxiv a license to display the preprint in perpetuity. It is made available under aCC-BY-ND 4.0 International license.

\section{Literature}

Akaya M, Takenaka C (2001) Effects of aluminum stress on photosynthesis of Quercus glauca Thumb. Plant Soil 237:137-146

Bartón K (2018) Package ‘MuMIn, 1.40 .4

Beaudet M, Messier C (2002) Variation in canopy openness and light transmission following selection cutting in northern hardwood stands: an assessment based on hemispherical photographs. Agric For Meteorol 110:217-228. https://doi.org/10.1016/S0168-1923(01)00289-1

Braak CJF ter, Peres-Neto PR, Dray S (2018) Simple parametric tests for trait-environment association. J Veg Sci 29:801-811. https://doi.org/10.1111/jvs.12666

Breshears DD, Ludwig JA (2010) Near-ground solar radiation along the grassland-forest continuum: Tall-tree canopy architecture imposes only muted trends and heterogeneity. Austral Ecol 35:3140. https://doi.org/10.1111/j.1442-9993.2009.02009.x

Bustamante MMC, Martinelli LA, Silva DA, et al (2004) 15N natural abundance in woody plants and soils of central brazilian savannas (cerrado). Ecol Appl 14:200-213. https://doi.org/10.1890/016013

Bustamante MMC, Medina E, Asner GP, et al (2006) Nitrogen cycling in tropical and temperate savannas. Biogeochemistry 79:209-237. https://doi.org/10.1007/s10533-006-9006-x

Chave J, Coomes D, Jansen S, et al (2009) Towards a worldwide wood economics spectrum. Ecol Lett 12:351-366. https://doi.org/10.1111/j.1461-0248.2009.01285.x

Cianciaruso MV, Silva IA, Batalha MA, et al (2012) The influence of fire on phylogenetic and functional structure of woody savannas: Moving from species to individuals. Perspect Plant Ecol Evol Syst 14:205-216. https://doi.org/10.1016/j.ppees.2011.11.004

Cianciaruso MV, Silva IA, Batalha MA (2009) Diversidades filogenética e funcional: novas abordagens para a Ecologia de comunidades. Biota Neotropica 9:93-103. https://doi.org/10.1590/S167606032009000300008

Coletta L, Nardoto GB, Latansio S (2009) Isotopic view of vegetation and carbon and nitrogen cycles in a Cerrado ecosystem, southeastern Brazil. Sci Agric 66:467-475

Cornelissen JHC, Lavorel S, Garnier E, et al (2003) A handbook of protocols for standardised and easy measurement of plant functional traits worldwide. Aust J Bot 51:335-380

Coutinho LM (1990) Fire in the Ecology of the Brazilian Cerrado. In: Goldammer DJG (ed) Fire in the Tropical Biota. Springer Berlin Heidelberg, pp 82-105

Craine JM, Brookshire ENJ, Cramer MD, et al (2015) Ecological interpretations of nitrogen isotope ratios of terrestrial plants and soils. Plant Soil 396:1-26. https://doi.org/10.1007/s11104-015-2542-1

Dalmagro HJ, Lobo F de A, Vourlitis GL, et al (2014) The physiological light response of two tree species across a hydrologic gradient in Brazilian savanna (Cerrado). Photosynthetica 52:22-35. https://doi.org/10.1007/s11099-014-0001-5

Dantas VL, Batalha MA, Pausas JG (2013) Fire drives functional thresholds on the savanna-forest transition. Ecology 94:2454-2463. https://doi.org/10.1890/12-1629.1

de Assis ACC de, Coelho RM, da Silva Pinheiro E da S, Durigan G (2011) Water availability determines physiognomic gradient in an area of low-fertility soils under Cerrado vegetation. Plant Ecol 212:1135-1147. https://doi.org/10.1007/s11258-010-9893-8 
bioRxiv preprint doi: https://doi.org/10.1101/2020.02.20.955955; this version posted February 20, 2020. The copyright holder for this preprint (which was not certified by peer review) is the author/funder, who has granted bioRxiv a license to display the preprint in perpetuity. It is made available under aCC-BY-ND 4.0 International license.

Demmig-Adams B, Adams WW (1992) Photoprotection and Other Responses of Plants to High Light Stress. Annu Rev Plant Physiol Plant Mol Biol 43:599-626. https://doi.org/10.1146/annurev.pp.43.060192.003123

Díaz S, Cabido M (2001) Vive la différence: plant functional diversity matters to ecosystem processes. Trends Ecol Evol 16:646-655. https://doi.org/10.1016/S0169-5347(01)02283-2

Dray S, Dufour A-B, Thioulouse and J, et al (2018) ade4: Analysis of Ecological Data: Exploratory and Euclidean Methods in Environmental Sciences. Version 1.7-11URL https://CRAN.Rproject.org/package $=$ ade 4

Durigan G, Ratter JA (2006) Successional changes in Cerrado and Cerrado/forest ecotonal vegetation in western São Paulo State, Brazil. Edinb J Bot 63:119-130. https://doi.org/10.1017/S0960428606000357

EMBRAPA (2006) Sistema Brasileiro de Classificação de Solos. Centro Nacional de Pesquisa de Solos, Rio de Janeiro

EMBRAPA (1997) Manual de métodos de análise de solo, 2nd edn. EMBRAPA - Centro Nacional de Pesquisa de Solos, Rio de Janeiro, Brazil

Felfili JM, Fagg CW (2007) Floristic composition, diversity and structure of the "cerrado" sensu stricto on rocky soils in northern Goiás and southern Tocantins, Brazil. Braz J Bot 30:375-385. https://doi.org/10.1590/S0100-84042007000300004

Ferri MG (1944) Transpiração de plantas permanentes dos cerrados. Bol Fac Filos Ciênc E Let USP Botânica 4:159-224

Franco AC, Rossatto DR, de Carvalho Ramos Silva L, da Silva Ferreira C (2014) Cerrado vegetation and global change: the role of functional types, resource availability and disturbance in regulating plant community responses to rising CO2 levels and climate warming. Theor Exp Plant Physiol 26:19-38. https://doi.org/10.1007/s40626-014-0002-6

Frazer GW, Canham CD, Lertzman KP (1999) Gap Light Analyzer (GLA): Imaging software to extract canopy structure and gap light transmission indices from true-colour fisheye photographs. Users Manual and Program Documentation, Version 2.0. Simon Fraser University and Institute of Ecosystem Studies, Burnaby, British Columbia

Furley PA, Ratter JA (1988) Soil Resources and Plant Communities of the Central Brazilian Cerrado and Their Development. J Biogeogr 15:97-108. https://doi.org/10.2307/2845050

Goldstein G, Rada F, Sternberg L, et al (1989) Gas exchange and water balance of a mistletoe species and its mangrove hosts. Oecologia 78:176-183. https://doi.org/10.1007/BF00377153

Goodland R (1971) A physiognomic analysis of the 'Cerrado' vegetation of central Brasil. J Ecol 59:411419. https://doi.org/10.2307/2258321

Goodland R, Pollard R (1973) The Brazilian Cerrado vegetation: a fertility gradient. J Ecol 61:219-224. https://doi.org/10.2307/2258929

Hocking PJ (2001) Organic acids exuded from roots in phosphorus uptake and aluminum tolerance of plants in acid soils. In: Advances in Agronomy. Academic Press, pp 63-97

Hoffmann WA (2002) Direct and Indirect Effects of Fire on Radial Growth of Cerrado Savanna Trees. J Trop Ecol 18:137-142

Hutley LB, O’Grady AP, Eamus D (2000) Evapotranspiration from Eucalypt open-forest savanna of Northern Australia. Funct Ecol 14:183-194. https://doi.org/10.1046/j.1365-2435.2000.00416.x 
bioRxiv preprint doi: https://doi.org/10.1101/2020.02.20.955955; this version posted February 20, 2020. The copyright holder for this preprint (which was not certified by peer review) is the author/funder, who has granted bioRxiv a license to display the preprint in perpetuity. It is made available under aCC-BY-ND 4.0 International license.

Jansen S, Broadley MR, Robbrecht E, Smets E (2002) Aluminum hyperaccumulation in angiosperms: a review of its phylogenetic significance. Bot Rev 68:235-269. https://doi.org/10.1663/00068101(2002)068[0235:AHIAAR]2.0.CO;2

Kochian LV (1995) Cellular mechanisms of aluminum toxicity and resistance in plants. Annu Rev Plant Physiol Plant Mol Biol 46:237-260. https://doi.org/10.1146/annurev.pp.46.060195.001321

Kohn MJ (2010) Carbon isotope compositions of terrestrial C3 plants as indicators of (paleo)ecology and (paleo)climate. Proc Natl Acad Sci U S A 107:19691-19695. https://doi.org/10.1073/pnas.1004933107

Kraft NJB, Cornwell WK, Webb CO, Ackerly DD (2007) Trait evolution, community assembly, and the phylogenetic structure of ecological communities. Am Nat 170:271-283. https://doi.org/10.1086/519400

Kunstler G, Falster D, Coomes DA, et al (2016) Plant functional traits have globally consistent effects on competition. Nature 529:204-207. https://doi.org/10.1038/nature16476

Lavorel S, Garnier E (2002) Predicting changes in community composition and ecosystem functioning from plant traits: revisiting the Holy Grail. Funct Ecol 16:545-556. https://doi.org/10.1046/j.1365-2435.2002.00664.X

Maarel E van der (2009) Vegetation Ecology. John Wiley \& Sons

Máguas C, Rascher KG, Martins-Loução A, et al (2011) Responses of woody species to spatial and temporal ground water changes in coastal sand dune systems. Biogeosciences 8:3823-3832. https://doi.org/10.5194/bg-8-3823-2011

Marshall J, Brooks R, Lajtha K (2007) Sources of variation in the stable isotopic composition of plants. In: Michener R, Lajtha K (eds) Stable Isotopes in Ecology and Environmental Science. Wiley Blackwell, Malden, pp 22-60

Materechera S, Mandiringana O, Mbokodi P, Nyamapfene K (1998) Organic matter, pH and nutrient distribution in soil layers of a savanna Thornveld sUbjected to different burning frequencies at Alice in the Eastern Cape. South Afr J Plant Soil 15:109-115

Meira-Neto JAA, da Silva MCNA, Tolentino GS, et al (2018) Shading, nitrogen and soil texture rule a sandy savanna: Does facilitation rule its patchy physiognomy as well? Flora 239:45-51. https://doi.org/10.1016/j.flora.2017.11.007

Meira-Neto JAA, Tolentino GS, da Silva MCNA da, et al (2017) Functional antagonism between nitrogen-fixing leguminous trees and calcicole-drought-tolerant trees in the Cerrado. Acta Bot Bras 31:11-18. https://doi.org/10.1590/0102-33062016abb0380

Moles AT, Warton DI, Warman L, et al (2009) Global patterns in plant height. J Ecol 97:923-932. https://doi.org/10.1111/j.1365-2745.2009.01526.x

Motta P, Curi N, Franzmeier D (2002) Relation of Soils and Geomorphic Surfaces in the Brazilian Cerrado: Ecology and Natural History of a Neotropical Savanna. In: The Cerrados of Brazil: ecology and natural history of a neotropical savanna, OLIVEIRA, P.S. \& MARQUIS, R.J. Columbia University Press, Chicago

Mueller-Dombois D, Ellenberg H (2003) Aims and Methods of Vegetation Ecology. Blackburn Press

Neri AV, Schaefer CEGR, Silva AF, et al (2012) The influence of soils on the floristic composition and community structure of an area of Brazilian Cerrado vegetation. Edinb J Bot 69:1-27. https://doi.org/10.1017/S0960428611000382

Neri AV, Schaefer CEGR, Souza AL, et al (2013) Pedology and plant physiognomies in the cerrado, Brazil. An Acad Bras Ciênc 85:87-102. https://doi.org/10.1590/S0001-37652013000100007 
bioRxiv preprint doi: https://doi.org/10.1101/2020.02.20.955955; this version posted February 20, 2020. The copyright holder for this preprint (which was not certified by peer review) is the author/funder, who has granted bioRxiv a license to display the preprint in perpetuity. It is made available under aCC-BY-ND 4.0 International license.

Oliveira-Filho A, Ratter JA (2002) Vegetation physiognomies and woody flora of the Cerrado Biome. In: The Cerrados of Brazil: ecology and natural history of a Neotropical savanna. Columbia University Press, New York, pp 91-120

Oliveira-Filho AT, Jarenkow JA, Rodal M (2006) Floristic relationships of seasonally dry forests of eastern South America based on tree species distribution patterns. In: Neotropical savannas and seasonally dry forests: plant diversity, biogeography, and conservation, R . Toby Pennington, Gwilym P . Lewis, and James A . Ratter eds. CRC Press, pp 159-192

Peres-Neto PR, Dray S, Braak CJF ter (2017) Linking trait variation to the environment: critical issues with community-weighted mean correlation resolved by the fourth-corner approach. Ecography 40:806-816. https://doi.org/10.1111/ecog.02302

Pérez-Harguindeguy N, Díaz S, Garnier E, et al (2013) New handbook for standardised measurement of plant functional traits worldwide. Aust J Bot 61:167-234

Pinheiro LFS, Kolb RM, Rossatto DR (2016) Changes in irradiance and soil properties explain why typical non-arboreal savanna species disappear under tree encroachment. Aust J Bot 64:333-341. https://doi.org/10.1071/BT15283

R Development Core Team (2015) R: A language and environment for statistical computing. http://www.R-project.org/. Accessed 19 Feb 2015

Rachid M (1947) Transpiração e sistemas subterrâneos da vegetação de verão dos campos cerrados de Emas. Bol Fac Filos Ciênc E Let USP - Botânica 5:1-140

Ratter JA, Bridgewater S, Ribeiro JF (2003) Analysis of the floristic composition of the Brazilian Cerrado vegetation III: comparison of the woody vegetation of 376 areas. Edinb J Bot 60:57-109. https://doi.org/10.1017/S0960428603000064

Ratter JA, Montgomery R, Askew D, Gifford DR (1977) Observações adicionais sobre o cerradão de solos mesotróficos no Brasil Central. In: IV Simpósio Sobre o Cerrado. Itatiaia, São Paulo, pp 303-316

Rawitscher F, Ferri MG, Rachid M (1943) Profundidade dos solos e vegetacao em campos cerrados do Brasil meridional. An Acad Bras Ciênc 15:267-294

Reich PB, Walters MB, Ellsworth DS (1997) From tropics to tundra: Global convergence in plant functioning. Proc Natl Acad Sci 94:13730-13734

Ribeiro JF, Walter BMT (1998) Fitofisionomias do Bioma Cerrado. In: Sano SM, Almeida SP (eds) Cerrado: ambiente e flora, S.M. Sano \& S.P. Almeida. Planaltina, pp 89-166

Riley D, Barber SA (1971) Effect of Ammonium and Nitrate Fertilization on Phosphorus Uptake as Related to Root-Induced pH Changes at the Root-Soil Interface. Soil Sci Soc Am J 35:301. https://doi.org/10.2136/sssaj1971.03615995003500020035x

Rizzini CT (1963) A flora do Cerrado: análise florística das savanas centrais. In: Simpósio sobre o Cerrado. Editora da Universidade de São Paulo, São Paulo, pp 125-177

Rossatto DR, de Carvalho Ramos Silva L, Villalobos-Vega R, et al (2012) Depth of water uptake in woody plants relates to groundwater level and vegetation structure along a topographic gradient in a neotropical savanna. Environ Exp Bot 77:259-266. https://doi.org/10.1016/j.envexpbot.2011.11.025

Ruggiero PGC, Batalha MA, Pivello VR, Meirelles ST (2002) Soil-vegetation relationships in cerrado (Brazilian savanna) and semideciduous forest, Southeastern Brazil. Plant Ecol 160:1-16. https://doi.org/10.1023/A:1015819219386 
bioRxiv preprint doi: https://doi.org/10.1101/2020.02.20.955955; this version posted February 20, 2020. The copyright holder for this preprint (which was not certified by peer review) is the author/funder, who has granted bioRxiv a license to display the preprint in perpetuity. It is made available under aCC-BY-ND 4.0 International license.

Scartazza A, Lauteri M, Guido MC, Brugnoli E (1998) Carbon isotope discrimination in leaf and stem sugars, water-use efficiency and mesophyll conductance during different developmental stages in rice subjected to drought. Funct Plant Biol 25:489-498

Silva LCR, Hoffmann WA, Rossatto DR, et al (2013) Can savannas become forests? A coupled analysis of nutrient stocks and fire thresholds in central Brazil. Plant Soil 373:829-842. https://doi.org/10.1007/s11104-013-1822-X

Simon MF, Grether R, de Queiroz LP, et al (2009) Recent assembly of the Cerrado, a neotropical plant diversity hotspot, by in situ evolution of adaptations to fire. Proc Natl Acad Sci 106:2035920364. https://doi.org/10.1073/pnas.0903410106

Sprent JI (2009) Legume nodulation: a global perspective. Wiley-Blackwell, Chichester, UK

Sprent JI (2007) Evolving ideas of legume evolution and diversity: a taxonomic perspective on the occurrence of nodulation. New Phytol 174:11-25

Sprent JI, Geoghegan IE, Whitty PW, James EK (1996) Natural abundance of 15N and 13C in nodulated legumes and other plants in the cerrado and neighbouring regions of Brazil. Oecologia 105:440446. https://doi.org/10.1007/BF00330006

Ström L (1997) Root Exudation of Organic Acids: Importance to Nutrient Availability and the Calcifuge and Calcicole Behaviour of Plants. Oikos 80:459-466. https://doi.org/10.2307/3546618

Sugihara S, Shibata M, Ze ADM, et al (2014) Effect of vegetation on soil C, N, P and other minerals in Oxisols at the forest-savanna transition zone of central Africa. Soil Sci Plant Nutr 60:45-59. https://doi.org/10.1080/00380768.2013.866523

Symonds MRE, Moussalli A (2011) A brief guide to model selection, multimodel inference and model averaging in behavioural ecology using Akaike's information criterion. Behav Ecol Sociobiol 65:13-21. https://doi.org/10.1007/s00265-010-1037-6

The Angiosperm Phylogeny Group (2016) An update of the Angiosperm Phylogeny Group classification for the orders and families of flowering plants: APG IV. Bot J Linn Soc 181:1-20. https://doi.org/10.1111/boj.12385

Thomas DS, Montagu KD, Conroy JP (2006) Leaf inorganic phosphorus as a potential indicator of phosphorus status, photosynthesis and growth of Eucalyptus grandis seedlings. For Ecol Manag 223:267-274. https://doi.org/10.1016/j.foreco.2005.11.006

Townsend AR, Cleveland CC, Asner GP, Bustamante MMC (2007) Controls over foliar N:P ratios in tropical rain forests. Ecology 88:107-118. https://doi.org/10.1890/00129658(2007)88[107:COFNRI]2.0.CO;2

Valiente-Banuet A, Verdú M (2007) Facilitation can increase the phylogenetic diversity of plant communities. Ecol Lett 10:1029-1036. https://doi.org/10.1111/j.1461-0248.2007.01100.x

Werner C, Máguas C (2010) Carbon isotope discrimination as a tracer of functional traits in a mediterranean macchia plant community. Funct Plant Biol 37:467-477. https://doi.org/10.1071/FP09081

Westoby M (1998) A leaf-height-seed (LHS) plant ecology strategy scheme. Plant Soil 199:213-227. https://doi.org/10.1023/A:1004327224729

Wohlgemuth T, Gigon A (2003) Calcicole plant diversity in Switzerland may reflect a variety of habitat templets. Folia Geobot 38:443-452. https://doi.org/10.1007/BF02803251

Wright IJ, Reich PB, Westoby M (2001) Strategy shifts in leaf physiology, structure and nutrient content between species of high- and low-rainfall and high- and low-nutrient habitats. Funct Ecol 15:423-434. https://doi.org/10.1046/j.0269-8463.2001.00542.x 
bioRxiv preprint doi: https://doi.org/10.1101/2020.02.20.955955; this version posted February 20, 2020. The copyright holder for this preprint (which was not certified by peer review) is the author/funder, who has granted bioRxiv a license to display the preprint in perpetuity. It is made available under aCC-BY-ND 4.0 International license.

623 Wright IJ, Reich PB, Westoby M (2003) Least-Cost Input Mixtures of Water and Nitrogen for 624 Photosynthesis. Am Nat 161:98-111. https://doi.org/10.1086/344920 
626 Table 1. Plant traits used to analyze functional groups of a Cerrado community at Paraopeba Reserve, Minas Gerais. $\left({ }^{*}\right)$ indicates a trait that was not directly used in the data analysis, but which is part of a rate. $\mathrm{SLA}=$ specific leaf area, $\mathrm{Hmax}=$ maximum height, $\mathrm{Dmax}=$ maximum diameter, $\mathrm{C} / \mathrm{N}=$ carbon to nitrogen ratio of leaf.

\begin{tabular}{|c|c|c|}
\hline Trait & Unit & Functional significance \\
\hline 1. SLA & $\mathrm{mm}^{2} \cdot \mathrm{mg}^{-1}$ & $\begin{array}{l}\text { Correlated with aspects of physiology related to the efficiency of } \\
\text { resource uptake and use }\end{array}$ \\
\hline 2. $\operatorname{Hmax}^{*}$ & $\mathrm{~m}$ & \multirow{2}{*}{ Reflects competitive vigour and ability to persist after disturbances } \\
\hline 3. Dmax* & $\mathrm{cm}$ & \\
\hline 4. Hmax/Dmax & - & Stem elongation considering vertical/horizontal growth \\
\hline 5. $\mathrm{C} / \mathrm{N}$ & - & Indicates nitrogen limitation, proxy of nutritional status \\
\hline 6. N\% & - & Indicates leaf nitrogen content, proxy of nutritional status \\
\hline 6. $\mathrm{C} \%$ & - & $\begin{array}{c}\text { Indicates leaf carbon content, proxy of polysaccharides and } \\
\text { photoassimilates }\end{array}$ \\
\hline
\end{tabular}

Indicates if a species is adapted to poor soils and to high disturbance

6. Bark thickness $\quad \mathrm{mm} \quad$ regimes: the thicker the bark, the poorer the soil and the higher disturbance resistance

7. Wood density $\quad$ mg.mm $\mathrm{mm}^{-3} \quad$ Key trait for plant growth



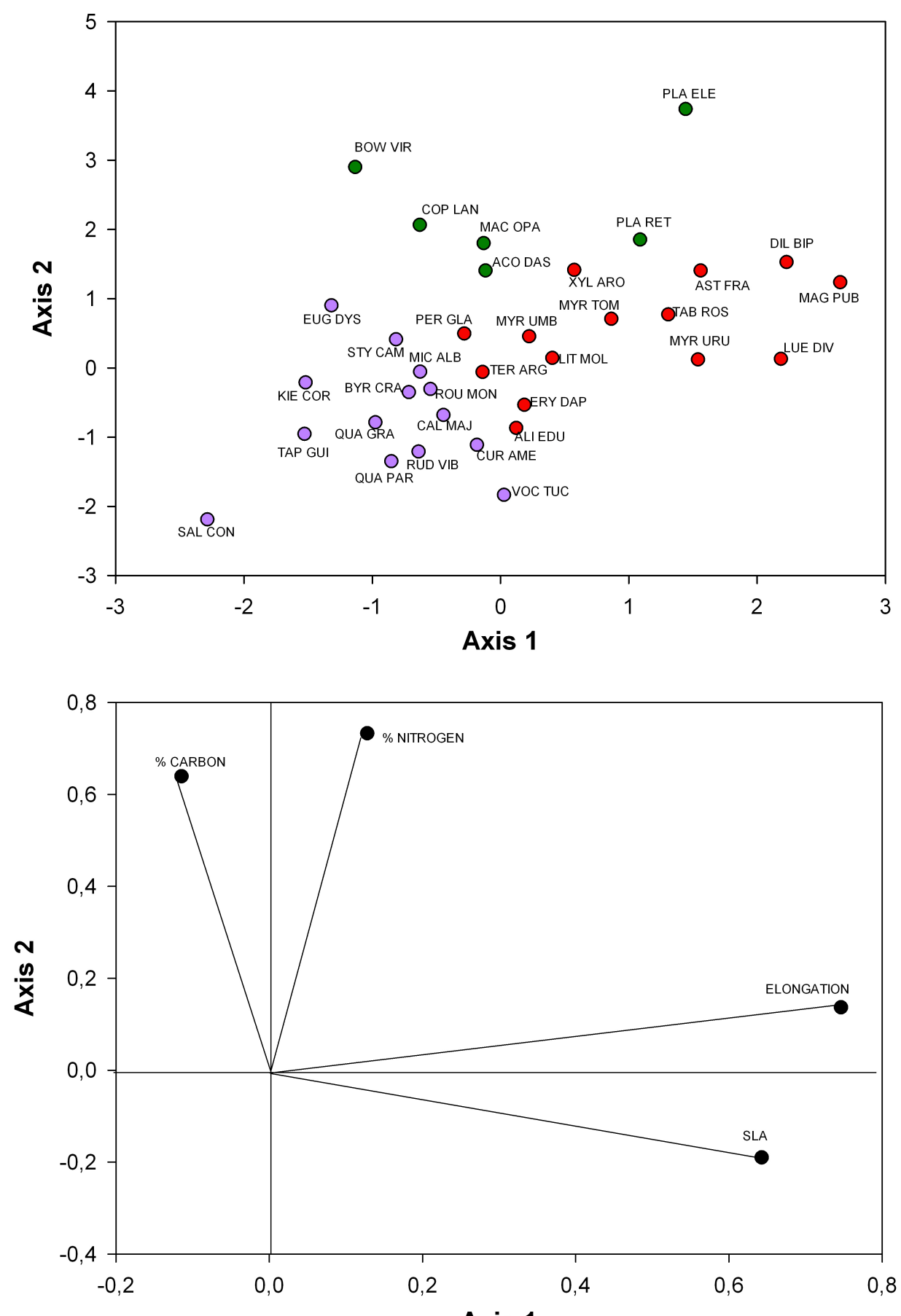

Axis 1

Figure 1- Canonical RLQ ordination of 34 woody species and environmental variables; red dots are calcicole species (CAL), green dots are leguminous species (LEG), purple dots are savanna species (SAV). SLA - specific leaf area, elongation - maximum height to maximum diameter ratio, $\%$ nitrogen - leaf nitrogen content $(\%), \%$ carbon - leaf carbon content $(\%)$. 
bioRxiv preprint doi: https://doi org/10.1101/2020.02 20.955955; this version posted February 20,2020 . The copyright holder for this preprint (which was not certified by peer review) is the author/funder, who has granted bioRxiv a license to display the preprint in perpetuity. It is made available under aCC-BY-ND 4.0 International license.

631

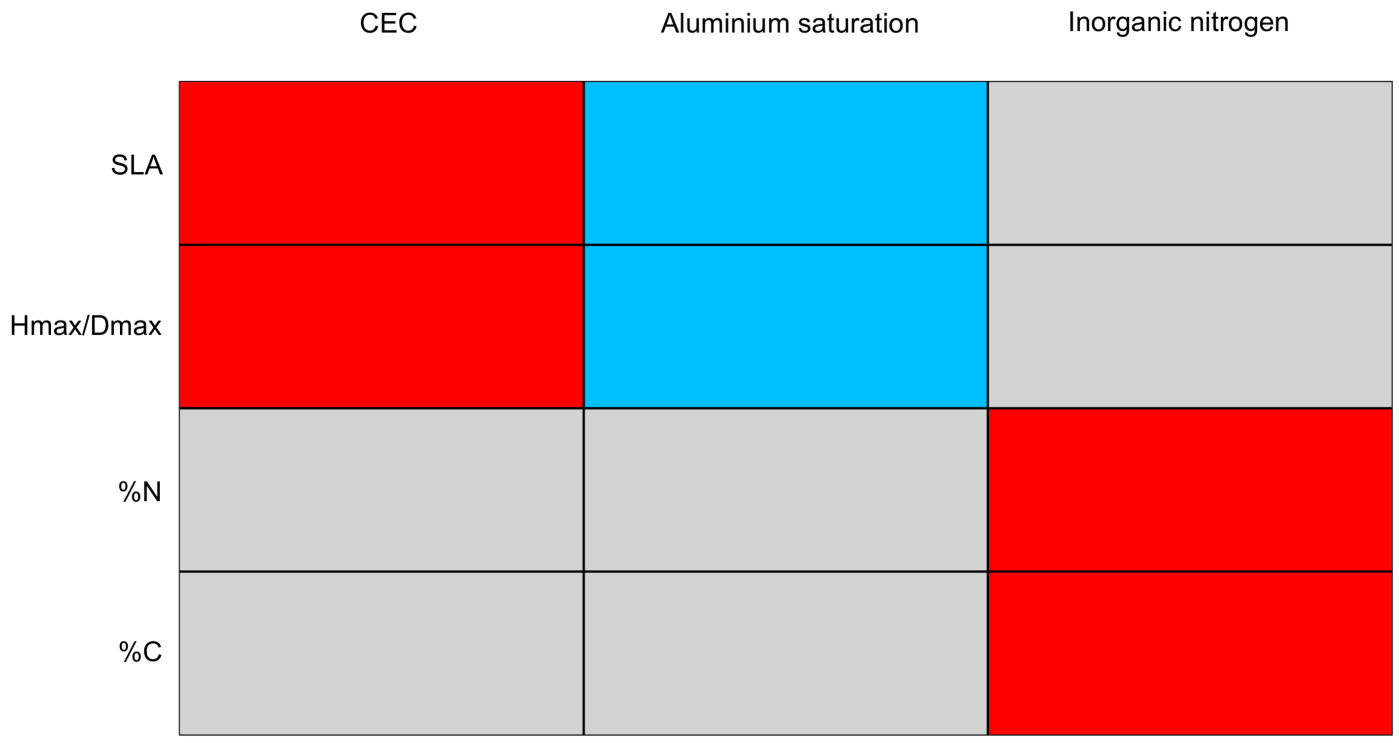

633 Figure 2. Results of the fourth-corner analysis. Adjusted significances of positive relations: between Cation

634 Exchange Capacity (CEC) and specific leaf area (SLA), P value adjusted $=0.044$; between CEC and stem

635 elongation $(\operatorname{Hmax} / \mathrm{Dmax}), \mathrm{P}$ value adjusted $=0.044$; between inorganic nitrogen and leaf nitrogen

636 percentage $(\% \mathrm{~N}), \mathrm{P}$ value adjusted $=0.040$; between inorganic nitrogen and leaf carbon percentage $(\% \mathrm{C})$,

$637 \quad \mathrm{P}$ value adjusted $=0.044$. Adjusted significances of negative relations: between aluminium saturation $(\mathrm{m})$

638 and specific leaf area (SLA), $\mathrm{P}$ value adjusted $=0.044$; between aluminium saturation and Hmax/Dmax, $\mathrm{P}$

639 value adjusted $=0.024$. 

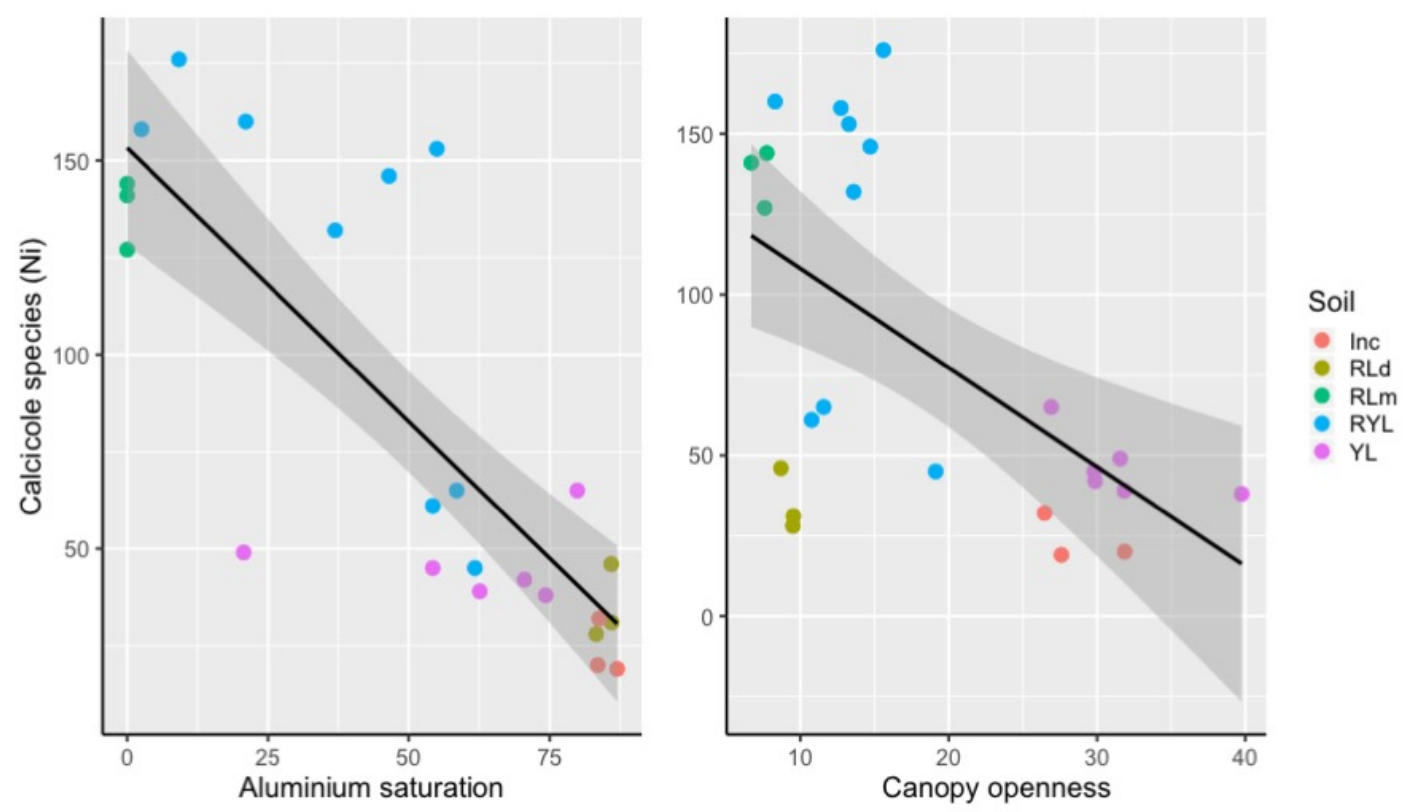

643 Figure 3. The best GLM full models for Calcicole species ( $\mathrm{Ni}=$ abundance) in relation to

644 soil and canopy openness in the Cerrado of Paraopeba Reserve. Model: glm (CAL Al

645 saturation + Inorganic nitrogen $+\mathrm{CEC}+$ Canopy openness $+\mathrm{pH}$, family=poison), delta

646 AIC $<2$. Dots are 20-m x 20-m plots. Soil: Inc - Cambisol (Inceptisol); RLd - dystrophic

647 Red Latosol; RLm - mesotrophic Red Latosol; RYL - Red-Yellow Latosol; YL - Yellow

648 Latosol. 

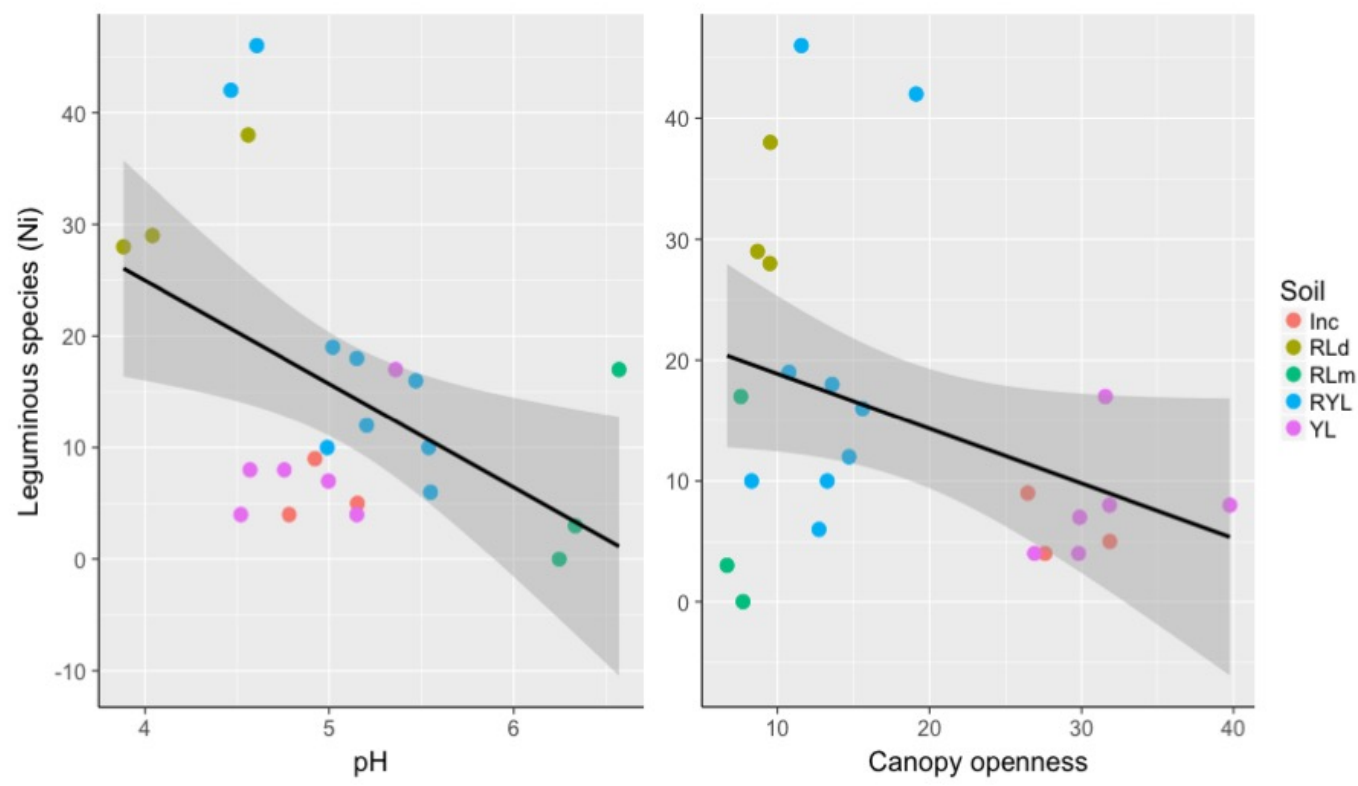

651 Figure 4. The best GLM full models for Leguminous species $(\mathrm{Ni}=$ abundance $)$ in relation 652 to soil and canopy openness in the Cerrado of Paraopeba Reserve. Model: glm (CAL 653 Al saturation + Inorganic nitrogen $+\mathrm{CEC}+$ Canopy openness $+\mathrm{pH}$, family=poison), 654 Delta AIC < 2. Dots are 20-m x 20-m plots. Soil: Inc - Cambisol (Inceptisol); RLd 655 dystrophic Red Latosol; RLm - mesotrophic Red Latosol; RYL - Red-Yellow Latosol; 656 YL - Yellow Latosol. 

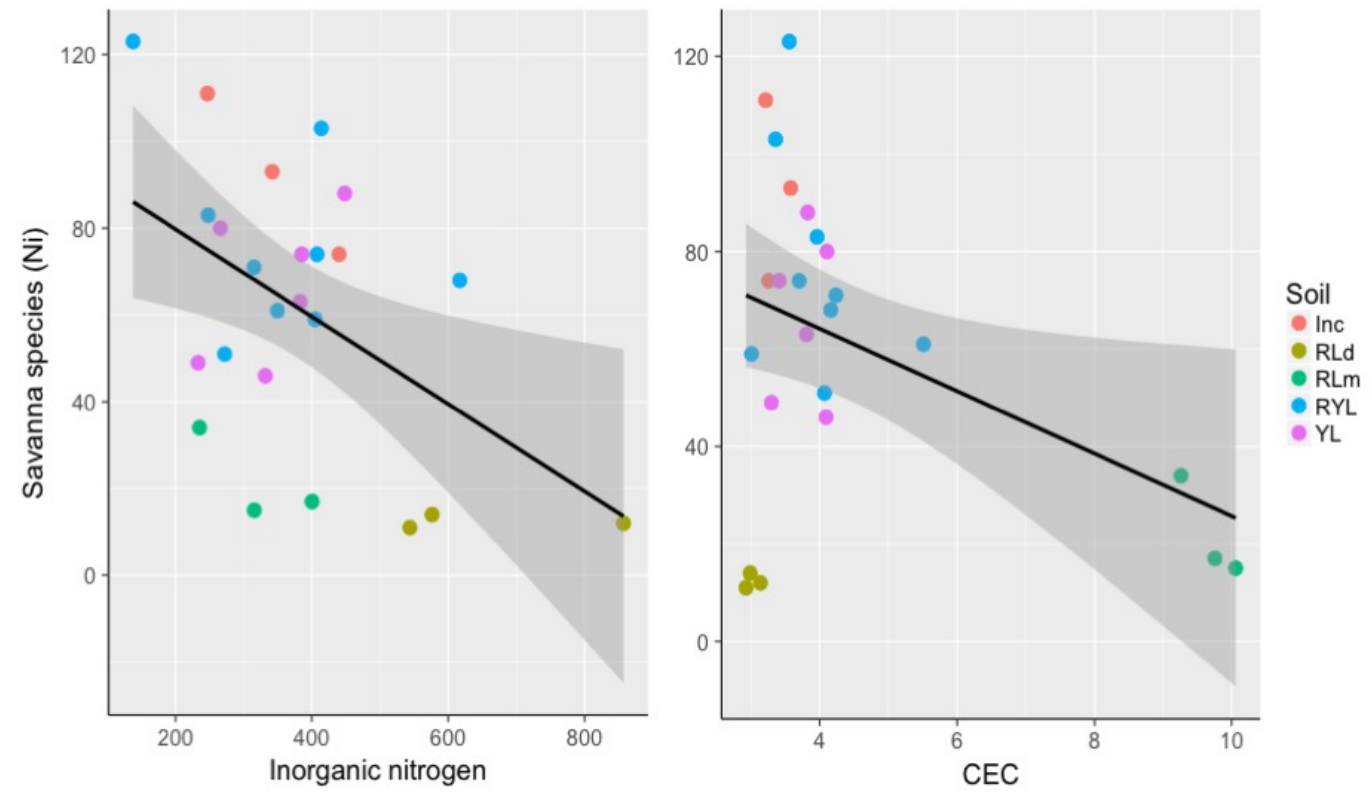

659 Figure 5. The best GLM full models for Savanna species $(\mathrm{Ni}=$ abundance) in relation to 660 soil and canopy openness in the Cerrado of Paraopeba Reserve. Model: glm (CAL Al

661 saturation + Inorganic nitrogen $+\mathrm{CEC}+$ Canopy openness $+\mathrm{pH}$, family=poison), Delta 662 AIC $<2$. Dots are 20-m x 20-m plots. Soil: Inc - Cambisol (Inceptisol); RLd - dystrophic 663 Red Latosol; RLm - mesotrophic Red Latosol; RYL - Red-Yellow Latosol; YL - Yellow 664 Latosol. 

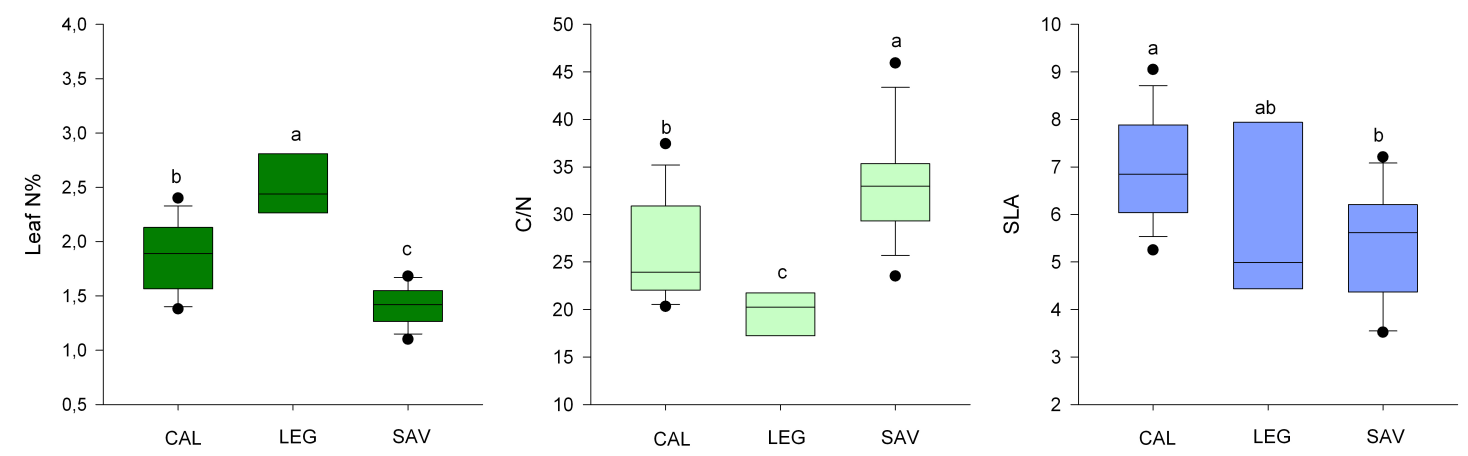

666 Figure 6. Box and whiskers plots of the GLMs for functional groups by functional traits.

667 Leaf nitrogen content (Leaf N\%), Leaf carbon to nitrogen ratio $(\mathrm{C} / \mathrm{N})$ and Specific leaf 668 area (SLA) by groups. Different lowercases letters indicate significant differences $669(\mathrm{p}<0.005)$ 

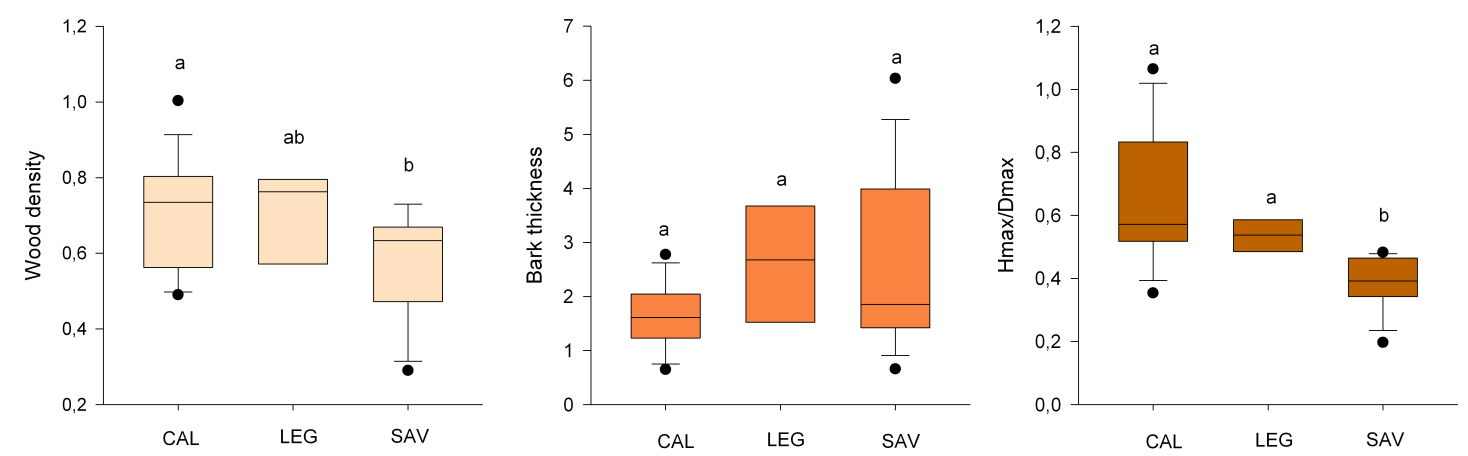

671 Figure 7. Box and whiskers plots of the GLMs for functional groups by functional traits.

672 Wood density, bark thickness and ratio of maximum height to maximum diameter (i.e.,

673 stem elongation, Hmax/Dmax) by groups. Different lowercases letters indicate significant

674 differences $(\mathrm{p}<0.005)$.

675 


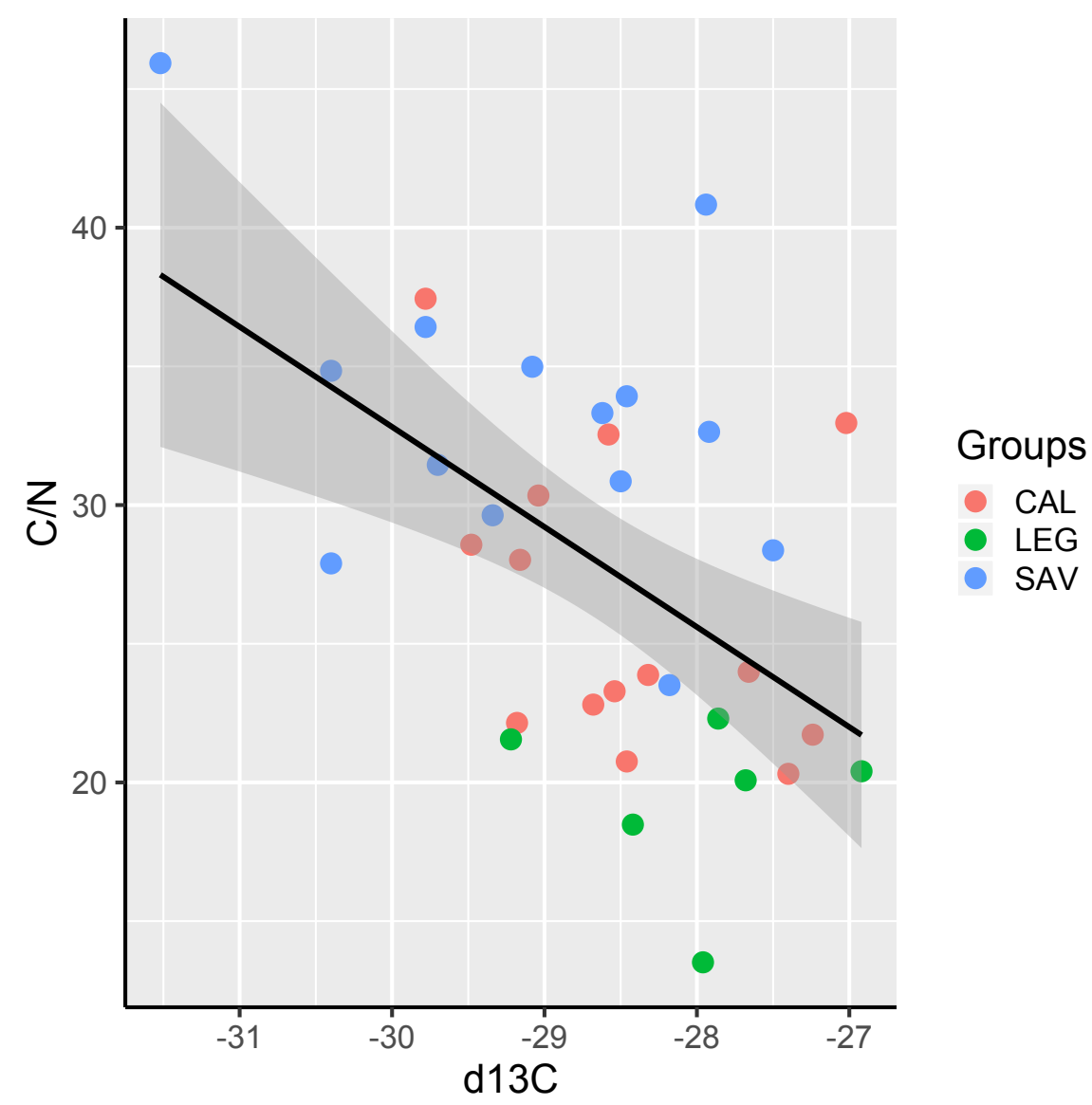

677 Figure 8. GLM of the best model for leaf $\mathrm{C} / \mathrm{N}$ in response to functional traits (SLA,

678 Hmax/Dmax, Bark thickness, leaf $\delta^{13} \mathrm{C}$ and leaf $\delta^{15} \mathrm{~N}$ ) of the 34 Cerrado plant species of 679 the three functional groups CAL and LEG and SAV. The best model is between leaf C/N 680 and leaf $\delta 13 C(\mathrm{~d} 13 \mathrm{C})$ values $(\mathrm{p}=0.00148)$. 


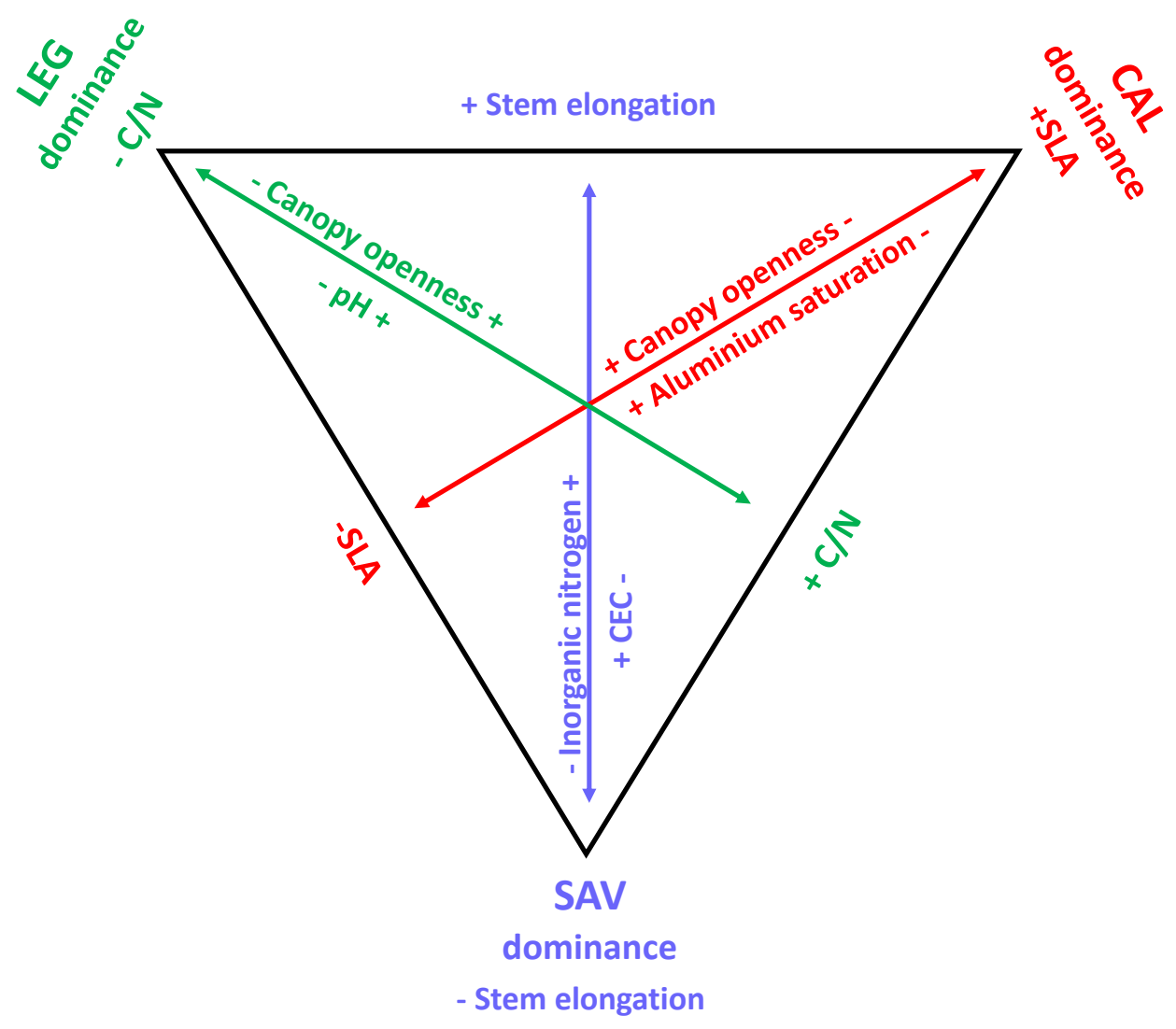

Figure 9. Model for the main gradients determining the distribution of the Calcicole species (CAL); the Leguminous species (LEG), the Savanna species (SAV); Inorganic N = inorganic nitrogen; $\mathrm{C} / \mathrm{N}=$ leaf carbon-to-nitrogen ratio; $\mathrm{pH}=$ hydrogenionic potential; $\mathrm{CEC}=$ cation exchange capacity. Arrows indicate the gradients where, at one extremity, one group preferentially occurs, on the other extremity, two other groups preferentially occur. 